\title{
Accounting Irregularities in Related Party Transactions
}

\author{
Akmalia M. Ariff and Hafiza A. Hashim
}

\begin{abstract}
This paper presents financial reporting issues surrounding Related Party Transactions (RPTs). While RPTs can be value-enhancing for companies, those that are used to expropriate shareholders' wealth may need to be shielded by accounting irregularities. We discuss the theoretical link between RPTs and accounting irregularities and review evidence on accounting irregularities involving RPTs. We also discuss issues with the existing evidence and suggest that future research should work towards identifying: a) the background of RPTs that served as expropriation mechanism, b) the types of RPTs that normally involved accounting irregularities, and c) the effect of accounting irregularities involving RPTs. The results of studies with such approach may benefit the regulators in curbing accounting irregularities, especially those that involved RPTs.
\end{abstract}

Index Terms-Related party transaction, accounting irregularities, Malaysia.

\section{INTRODUCTION}

This paper explores the relationship between Related Party Transactions (hereafter RPTs) and accounting irregularities. While RPTs can be normal transactions performed in the ordinary course of business, there are claims that RPTs can be used as expropriation mechanisms. This negative aspect of RPTs is exemplified by the high profile cases of accounting irregularities involving RPTs, such as Enron, Adelphia, and Tyco. We review theoretical and empirical evidence surrounding economic consequences of RPTs. Our review shows that RPTs that serve as expropriation mechanisms have greater tendency to be associated with accounting irregularities because accounting irregularities may be needed to rationalize, conceal or cover up the expropriation activities involving RPTs. Our review also indicates that the multifaceted nature of RPTs have created difficulties in their monitoring and auditing, and thus providing the opportunity for management to be involved with self-serving behavior that are detrimental to shareholders' wealth.

Nevertheless, there are mixed evidence on the economic consequences of RPTs. These mixed findings are partly caused by the different ways RPTs and accounting irregularities are measured in research. Many of the prior studies focus on the amount of RPTs disclosed in the notes to the financial statement and hence, may not be able to capture the 'true' value of RPTs. A more valuable research approach is to scrutinize corporate undertakings on RPTs in details,

Manuscript received October 14, 2013; revised December 15, 2013. The study is supported by Research Acculturation Grant Scheme (RAGS: Vote No. 57089) from the Ministry of Higher Education of Malaysia.

The authors are with Universiti Malaysia Terengganu, Kuala Terengganu, Terengganu, 21030 Malaysia (e-mail: akmalia.ariff@umt.edu.my, hafizaaishah@umt.edu.my). such as by differing them according to the types of transactions and the related parties.

Besides, the institutional context is often ignored in existing research on RPTs. With the many regulatory reforms taking place after the 1997 Asian financial crisis, including those that specifically focus on RPTs, we believe that governance mechanisms must be incorporated in research. We suggest future research to consider analysing RPTs using data from a cross-country sample for the purpose of understanding the role of governance on the link between RPTs and accounting irregularities. In short, more works need to be done to identify: a) the background of RPTs that served as expropriation mechanism, b) the types of RPTs that normally involved accounting irregularities, and c) the effect of accounting irregularities involving RPTs.

This paper proceeds as follows: Section 2.0 discusses the economic consequences of RPTs. Section 3.0 explains links between RPTs and accounting irregularities and Section 4.0 reviews existing literature. Section 5.0 discusses issues on the existing findings on RPTs and Section 6.0 concludes.

\section{THE ECONOMIC CONSEQUENCES OF RPTS}

Related party transactions (RPTs hereafter) refer to transactions that involve parties that have relation, in which the relation could be personal or of other kinds. In the current IAS, RPTs are defined as a transfer of resources, services, or obligations between related parties, regardless of whether a price is charged [1]. RPTs are often taken in the form of sales and purchases of assets, loan to and from related parties, and leases. All these are normal business transactions that fall into the scope of RPTs when they are executed with related parties who can either be those that are deemed to be related, or those where a related party relationship is presumed. Examples of related parties are board members, officers as well as controlling owners.

There are two competing perspectives on the economic consequences of RPTs. In the positive view of RPTs, RPTs are perceived as value-enhancing mechanisms that are designed to improve efficiency in an organization. RPTs as value-enhancing mechanisms have been discussed from the perspective of efficient transaction [2], contracting efficiency [3], bonding mechanisms [4] and institutional needs [5]. In the negative view of RPTs, RPTs are perceived as a form of private benefits of control, which is used as a mean of transferring firms' wealth to the controlling shareholders (or management) at the expense of other stakeholders. The abusive perspective of RPTs have been discussed according to the principal-agent conflict theory [2], expropriation mechanisms [4], and opportunistic and non-opportunistic 
behavior [3].

The two contradicting expectations regarding RPTs lead to two opposite predictions on the link between RPTs and accounting irregularities. If RPTs are value-enhancing mechanisms there is no association that can be predicted between RPTs and accounting irregularities. In these circumstances, RPTs are at par with any other business dealing with non-related entities. However, if RPTs are value-decreasing mechanisms, the link between RPTs and accounting irregularities can be expected to be positive. In these circumstances, accounting irregularities are used to rationalize, conceal or cover up the expropriation activities.

\section{ACCOUNTING IRREGULARITIES IN RPTS}

While there are two potential links between RPTs and accounting irregularities, RPTs have often been viewed skeptically by participants of the stock market. Reference [6] indicates that there are many high profile cases involving RPTs, such as Enron, Adelphia, and Tyco, that set negative perceptions on RPTs. RPTs are a matter of concern for outside shareholders, which in some way creating concern among regulators. Reference [6] indicates that the importance of RPTs is exemplified by the promulgation of specific standards for both reporting and auditing for RPTs in the United States. In the Malaysian setting, there are specific reforms on RPTs. For example, the Bursa Malaysia Listing Requirement has recently been amended to include a provision for poll voting for RPTs that require shareholder approval. These heightened interests by the regulators indicate that RPTs can potentially be detrimental to the shareholders' wealth. Complaints about RPTs are worldwide phenomenon [7], including in East Asia where abusive RPTs are motivated by the relationship-based corporate governance and business systems in the region and facilitated by the inappropriate institutional, law and legal enforcement that shields controlling shareholders from internal governance structure.

The risk of abusive RPTs is huge, including leading to accounting irregularities. The complicated nature of RPTs makes them a potential target for such opportunistic behavior. Reference [8] indicates that there are significant complexity and risks associated with recognition and disclosure of RPTs. This is because the 'substance-over-form' issues are common with RPTs and some RPTs are embedded in documentation that is less clear or thorough than the documentation that ordinarily exists between unrelated parties. Reference [9] find that while relevant tax law and regulations specify that prices for RP sales should be set according to market prices as used in arm's length transactions, practices may not be so. There is a possibility that transfer prices is treated as a mechanism to transfer resources between different stakeholders for the purpose of giving gains to some and losses to others. For RPTs, where monitoring and auditing such transaction are difficult, there are incentives for management to be involved with permanent earnings manipulation.

The complex nature of RPTs makes it easy for RPTs to 'escape' from the auditors' and regulators' oversight. Reference [10], in reviewing corporate scandals, highlights the difficulties that auditors and regulators face in identifying RP relationships and transactions that are motivated by fraud or illicit earnings management. Reference [2] highlights three reasons for the difficulties in auditing RPTs; 1) transactions with related parties are not always identifiable, 2) the auditor relies primarily upon management and principal owners to identify all related parties and RPTs, and 3) RPTs may not be easily tracked by a company's internal control. In investigating the perceived importance of red flags, [11] find that "Significant and unusual related-party transactions are present" is listed as one of the most important fraud risk indicators. For the external auditor, the item is ranked first, whereas for economic crime investigator, the item is ranked third among the top 10 indicators.

In studies on the determinants of frauds, RPTs are used to proxy for 'opportunity' component of fraud triangle. Referring to the fraud triangle model proposed in 1953 by Cressey, RPTs provide the opportunity for fraud because they are complicated transactions with high inherent risk, as well as high possibility of manipulation by management [12]. Reference [13] highlights RPTs as opportunity risk factor in external auditors' client risk assessments. As mentioned in the TSAS 43, fraudulent financial reporting can arise in 'significant related-party transactions not in the ordinary course of business or with related entities not audited or audited by another firm'. In discussing fraudulent disclosures that mostly relate to purposeful omission, [14] classifies RPTs as one of the five categories of fraudulent disclosures. In RPTs, fraudulent disclosures normally involve an executive with an undisclosed financial interest in other entity. In the context of purposeful omission, fraudulent disclosures involving RPTs can elude easy detection by auditor. In discussing methods to detect financial statement fraud, RPTs are considered one of the most common methods of fraud [15]. For example, RPTs can be used to overstate assets or understate liabilities as amounts due to or from affiliates, as well as through purchase and sales from affiliates.

\section{ISSUES SURROUNDING ACCOUNTING IRREGULARITIES IN RPTS}

Discussion in Section II and III suggest that there is a link between RPTs and accounting irregularities. However, the complex nature of transactions involving RPTs has led to uncertainties on the economic consequences of RPTs and how they affect financial reporting practice. This conflicting phenomenon is more apparent in an emerging market such as Malaysia, where both the cost and benefits of RPTs are prevalent and significant. To add more understanding on the issues surrounding RPTs, we review reports and prior studies to gather evidence on RPTs and accounting irregularities.

Analysis of fraudulent financial reporting in the US, from 1998 to 2007 , reports that fraud firms disclosed significantly more related party transactions than non-fraud firms [16]. The report also identifies that $18 \%$ of the fraud firms misstate their financial statements by disguising them through use of RPTs. The higher frequency of related party transactions for fraud firms suggests that the presence of related party transactions may reflect heightened fraud risk. For Asian 
countries, fraud incidences are detailed out in a report titled 'Related-Party Transactions: Cautionary Tales for Investors in East Asia [17]. Among the cited cases are the expropriation of wealth incidence involving sales and purchases of assets between related parties in Hong Kong listed Pacific Challenge Capital and fraud and embezzlement in Hong Kong listed Kelon Electrical Holdings Company. The report also provides evidence on cases involving deprivation of wealth such as through appropriation of control in Korean listed Samsung Group and privatization and buyout of strategic assets in Singapore listed Pacific Century Regional Development.

In the context of Malaysia, [5] highlights the case of Transmile Bhd for which two Independent Non-executive Directors were sentenced a one-year prison term. In that case, sales and real estate transactions between insider directors and executives were abused, resulting in detrimental effect to the minority shareholders. Bursa Malaysia media releases for the year 2012 highlights one case of actions that involve RPTs. In the case involving KNM group, the company and eight of its directors are publicly reprimanded and fined a total of RM200,000. The case relates to an announcement of a proposal by BlueFire Capital Group, an entity controlled by the KNM group Managing Director himself, to acquire the entire business and undertakings of KNM. Despite the lack of disclosure on some material information, which is the Conditions of the offer, the directors approved the announcement. It is possible that the conflicts of interest that exist may have led to the approval decision, rather than the true understanding on the content of the transactions. More recently, The Edge reports the accounting irregularities involving RPTs in Patimas Computers Bhd [18]. In the case involving inflation of revenue through fictitious entries for sales, conflict of interest exists in some of the transactions as a person with directorship positions in four different companies involved was also connected to a director of Patimas. The UHY Advisory (KL) Sdn. Bhd's audit reveals that there was no declaration made on such connection for the said transactions.

Evidence linking between RPTs and accounting irregularities is limited and mixed. Reference [4] investigates whether RPTs are associated with earnings management. The incentive for earnings management may arise for the purpose of concealing RPTs that are used to expropriate a firm's resources. They argue that executives or board members have the incentives to manage earnings to justify the perquisite or mask extraction of the firm's resources. However, in the event that RPTs serve as the bonding mechanism, incentive for earnings management may not exists. Their results indicate evidence of the association between RPTs and earnings management. However, the associations are noted only for certain types of RPs and with certain types of information. For example, a positive association is shown for fixed-rate financing from related parties. They argue that the incentive to manage earnings exist in this situation because of the need to obtain future financing and repay the related party. The study also shows a negative association for RPTs with an executive chairman or the executive chairman's business. They argue that such RPTs bind the chairman to the company, limiting incentive for risk-taking behavior such as earnings management.

In [12] percentage of RPTs sales is used as a proxy for complicated transactions that create opportunity for fraud. They find that firm with higher percentage of RPTs sales accompanies higher probability of fraud. Similarly, [13] relies on level of related party sales to represent the opportunity component of the fraud triangle. They find that firms with more RPTs are associated with higher likelihood of fraudulent financial reporting. In a study that employs data from the Malaysian market, [5] uses the existence of RPTs as a proxy for 'rationalization' for fraudulent financial reporting (FFR). RPTs are measured by the number of separate RPTs disclosed in each company's annual report. Contrary to their expectation, they find that fraud firms have fewer RPTs than no-fraud firms. They argue that the results could be attributable to the fact that most of the fraud sample is unaffiliated focused groups firms while the no-fraud sample mostly consists of affiliated firms with diversified business groups. For emerging markets such as Malaysia, their results may be related to the importance of RPTs to the affiliated firms.

Reference [6] examines SEC enforcement actions that involved fraud and compare fraud cases involving RPTs with comparable fraud cases that did not involve such transactions. They find that fraud-related RPTs had a lower impact in financial statements but are more likely to involve misappropriation and to involve a top executive in some aspects of the fraud. Their result shows that the most frequent types of transactions in the enforcement were loans to related parties and payments to company officers for goods or services that were either unapproved or do not exists.

In [3] RPTs are categorized into two types; ex-ante RPTs and ex-post RPTs and different predictions are set on their effect. Ex-ante RPTs are transactions that originate before a firm becomes a publicly traded entity or before the counterparty becomes a related party, whereas ex-post RPTs are transactions that occur after the firm goes public and after the counterparty to the transaction obtains related party status. They posit that these two categories of RPTs have differing impact on shareholders' wealth. More specifically, the ex-post RPTs are more likely used to expropriate value from outside shareholders as compared to the ex-ante RPTs which are more likely to be efficient contracting arrangements benefiting shareholders. In one of their analysis, they find that ex-post RPTs are significantly related positively related to the likelihood that a firm enters financial distress or deregisters its securities.

Overall, review of the evidence involving accounting irregularities in RPTs show some support for the link between RPTs and accounting irregularities. However, existing evidence are not only limited but also inconsistent. This inconsistency is apparent especially when different measures of RPTs are used. In general, the economic consequences of RPTs are not clearly established in existing studies on RPTs and accounting irregularities.

\section{CONCLUSION}

In this study, we discuss the tendency of firms to be 
involved with accounting irregularities to conceal the abusive RPTs. We review theoretical and empirical evidence on the association between RPTs and accounting irregularities. Our review shows that, as complex corporate transactions, RPTs are seen as an opportunity or channel for fraudulent behaviour among managers and directors. Despite the negative view on RPTs, empirical evidence is not sufficient to indicate that firms with high involvement in RPTs have greater tendency to be involved with accounting irregularities.

Our review contributes to understanding on the quality of financial reporting quality, generally, and RPTs information specifically. In general, we propose that more research is needed to capture the true economic impact of RPTs. The mixed findings from prior studies indicate that no conclusive evidence can be seen on the link between RPTs and accounting irregularities. Issues involving measures of RPTs and accounting irregularities are some of the obstacles in these research areas. We recommend future studies to thoroughly evaluate the background of RPTs for the purpose of differentiating between RPTs that served as expropriation mechanism than others that do not. This can be done by developing a voluntary disclosure index to measure the breadth and depth of information on RPTs. By doing so, future research would be able to identify the way accounting irregularities are employed to cater for the abusive RPTs. Without gaining in depth understanding of the corporate undertakings involving RPTs, association between RPTs and accounting irregularities may not be clearly established.

Further, prior studies lack focus on institutional context. More specifically, there is a need to consider the role of governance in analyzing financial reporting quality. As the quality of governance influence managerial incentive in corporate undertakings, it is not fair to simply assume that the economic effects of RPTs are equivalent across firms and across countries. Besides, the recent reforms that have been taken to deal with abusive RPTs, such as by adding a provision for poll voting for RPTs that require shareholder approval in the Bursa Malaysia Listing Requirement, need to be incorporated in future research. A more rich understanding on the institutional context influencing the economic effects of RPTs can be derived from future studies that focus on using data from a cross-country sample.

\section{REFERENCES}

[1] IAS24, IFRS Foundation International Financial Reporting Standards, 2009.

[2] E. A. Gordon, E. Henry, and D. Palia, "Related party transactions and corporate governance," in Corporate Governance (Advances in Financial Economics), M. Hirschey, K. John, A. K. Makhija, Eds. Bingley, UK: Emerald Group Publishing Limited, 2005, pp. 1-27.

[3] M. Ryngaert and S. Thomas, "Not All Related Party Transactions (RPTs) are the same: Ex Ante Versus Ex Post RPTs," Journal of Accounting Research, vol. 50, no. 3, pp. 845-882, Feb. 2012.

[4] E. A. Gordon and E. Henry. (Nov. 2005). Related party transactions and earnings management. [Online]. Available: http://papers.ssrn.com/sol3/papers.cfm?abstract_id=612234

[5] S. Hasnan, R. A. Rahman, and S. Mahenthiran, "Management motive, weak governance, earnings management, and fraudulent financial reporting: malaysian evidence," Journal of International Accounting Research, vol. 12, no. 1, pp. 1-27, Spring 2012.

[6] E. Henry, E. A. Gordon, B. Reed, and T. Louwers, "The role of related party transactions in fraudulent financial reporting," Journal of
Forensic \& Investigative Accounting, vol. 4, no. 1, pp. 186-213, June 2012.

[7] OECD, "Guide on fighting abusive related party transactions in Asia," Corporate Governance Series, Organisation for Economic Co-Operation and Development, 2009, pp. 1-67.

[8] R. M. Pucek and G. E. Richards. (June 2013). What's a little debt between friends? How to apply accounting rules for related-party transactions. Journal of Accountancy. [Online]. vol. 6. Available: http://www.journalofaccountancy.com/Issues/2013/Jun/20126740.htm

[9] A. W. Y. Lo, R. M. K. Wong, and M. Firth, "Can corporate governance deter management from manipulating earnings? Evidence from related-party sales transactions in China," Journal of Corporate Finance, vol. 16, no. 2, pp. 225-235, April 2010.

[10] J. A. McCahery and E. P. M. Vermeulen, "Corporate governance crises and related party transactions: A post-Parmalat agenda," in Changes of Governance in Europe, Japan and US, K. J. Hopt et al., Eds. Oxford, UK: University Press, 2005, pp. 215-245.

[11] B. Gullkvist and A. Jokipii, "Perceived importance of red flags across fraud types," Critical Perspectives on Accounting, vol. 24, no.1, pp. 44-61, Feb. 2013.

[12] Y. I. Luo and M. L. Wang, "Fraud risk factor of the fraud triangle assessing the likelihood of fraudulent financial reporting," Journal of Business \& Economics Research, vol. 7, no. 2, pp. 61-78, Feb. 2009.

[13] K. Y. Chen and R. J. Elder, "Fraud risk factors and the likelihood of fraudulent financial reporting: Evidence from statement on Auditing Standards No. 43 in Taiwan," Working Paper, National Taiwan University and Syracuse University, vol. 36, 2007.

[14] J. T. Well. (July 2001). And nothing but the truth: uncovering fraudulent disclosures. Journal of Accountancy. [Online]. 7. Available: http://www.journalofaccountancy.com/Issues/2001/Jul/AndNothingB utTheTruthUncoveringFraudulentDisclosures

[15] E. E. Colby. Financial Statement Fraud. [Online]. Available: https://www.cga-pdnet.org/.../FinStatFraud/FinStatFraud_p3.pdf

[16] M. S. Beasley, J. V. Carcello, D. R. Hermanson, and T. L. Neal, Fraudulent Financial Reporting 1998-2007: An Analysis of U.S. Public Companies, The Committee of Sponsoring Organizations of the Treadway Commission (COSO), 2010, pp. 1-60

[17] CFA Institute, Related-Party Transactions: Cautionary tales for investors in East Asia, CFA Institute Centre for Financial Market Integrity, 2009, pp.1-40.

[18] S. Kumar. (May 2013). Patimas Audit Reveals Irregularities. The Edge: Malaysia. Available: http://www.theedgemalaysia.com/business-news/238856-patimas-aud it-reveals-irregularities.html

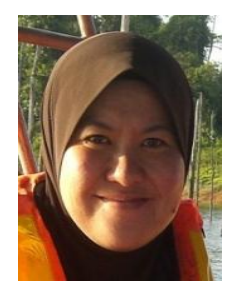

Akmalia M. Ariff has a Ph.D. in accounting obtained from the University of Auckland, New Zealand in 2011. Her field of study is financial reporting quality related to voluntary disclosure of intangibles from the perspective of East Asian markets.

She is currently a lecturer at the Faculty of Management and Economics, Universiti Malaysia Terengganu, Terengganu, Malaysia. She publishes in the area of financial reporting and corporate governance. Her research interests are financial reporting quality, voluntary disclosures, market valuation, and East Asian studies.

Dr. Mohamad Ariff is an associate member of the Malaysian Institute of Accountants. Her most recent award is being listed on the University of Auckland's Dean of Graduate Studies List in recognition of excellence achieved with her Ph.D. thesis.

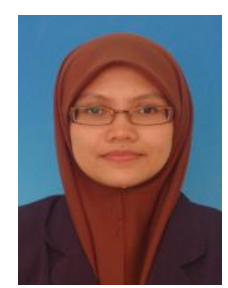

Hafiza A. Hashim has a Ph.D. in accounting from University of Malaya, Malaysia in 2009. Her field of study is financial reporting quality related to earnings management and corporate governance.

She is currently a senior lecturer at the Faculty of Management and Economics, Universiti Malaysia Terengganu, Terengganu, Malaysia. She publishes in the area of financial reporting and corporate governnce. Her research interests are earnings quality, earnings management, and ownership structure.

Dr. Hashim is an associate member of the Malaysian Institute of Accountants and Malaysian Finance Association. Her most recent award is Best Ph.D. Student awarded by the Graduate School of Business, Faculty of Business and Accountancy, University of Malaya. 